\title{
Processing and Enzymatic Treatment Effects on Louisiana-grown Fresh Satsuma Juice
}

\author{
John C. Beaulieu ${ }^{1}$ and Maureen A. Tully \\ U.S. Department of Agriculture, Agricultural Research Service, Southern Regional Research Center, \\ Food Processing and Sensory Quality, 1100 Robert E. Lee Boulevard, New Orleans, LA 70124 \\ Rebecca E. Stein-Chisholm \\ 15510 Quorum Drive \#3609, Addison, TX 75001 \\ Javier M. Obando-Ulloa \\ Departamento de Agroindustria y Enología, Centro de Estudios Postcosecha, Facultad de Ciencias \\ Agronómicas, Universidad de Chile, Ave. Santa Rosa 11315, La Pintana, Santiago, Chile
}

\begin{abstract}
AdDitional INDEX words. aroma, Citrus unshiu, terpenoid, ultrafiltration, volatiles
Abstract. A study was performed to evaluate the ability to rapidly produce fresh satsuma (Citrus reticulata) juice from local fruit with minimum processing inputs. Volatile flavor and aroma compounds, subjective assessments, and quality parameters were used to determine the changes that occur from different juice processing techniques, storage conditions, and enzymatic treatments. In freshly pressed Louisiana-grown satsuma juices, 44 compounds were recovered, of which 31 were positively identified. Based on volatile recovery and a consensus approach used in orangefleshed Citrus species reported in the literature, 19 compounds were evaluated. Limonene was the dominant integrated peak in all unpeeled and peeled pressed juices (PPJ). Peel removal resulted in $98.4 \%$ of the total volatiles being lost and the distribution of the volatiles remaining was markedly different compared with whole-pressed fruit juice. Aside from a $63.4 \%$ increase in valencene after enzyme treatments, there seemed to be no marked volatile, subjective, or quality improvements from the enzymes used in this study. In general, peeled pressed fruit produced an acceptable, mildly citrus-flavored, balanced acidity, sweet, not-from-concentrate juice. Concentrates made from PPJ and reconstituted satsuma juices indicated clearly that most desirable aroma/flavor volatile compounds were stripped from juices during concentrating. Data reported suggest more attention would be required to maintain the top notes and subtle volatile balance during commercialization in rapidly produced fresh satsuma juices through use of industrial equipment (peeler) or by adding back essence or flavor packs for consistent consumer satisfaction.
\end{abstract}

Satsuma is the most popular mandarin in Korea and Japan (Choi, 2004; Miyazawa et al., 2010). However, satsuma and satsuma juices have not attained such popularity in the United States. In 2002, the Louisiana citrus industry consisted of over 900 growers who produced roughly 1400 acres of citrus (Citrus sp.) for an estimated gross farm value of $\$ 7$ million to $\$ 8.8$ million (Lousiaina State University AgCenter, 2012; Shipp, 2002). This revenue was primarily attributed to satsuma, which have adapted well to the southern Louisiana growing conditions. In more recent post-hurricane (Katrina and Isaac) years, the Louisiana citrus industry has suffered immensely as a result of flooding, wind, and saltwater intrusions (Burdeau, 2005; Buskey, 2012), which led to a significant reduction in citrus production. According to the environmental working group farm subsidy database, farmers in Plaquemines Parish, LA, received $\$ 6.53$ million in commodity subsidies between 2005

Received for publication 10 Dec. 2013. Accepted for publication 16 Apr. 2014. Javier M. Obando-Ulloa's travel to and expenses to work in the U.S. Department of Agriculture in New Orleans, LA, were funded by the National Fund for Scientific and Technological Development (CONOCYT-FONDECYT), Ministry of Education, Chile.

Mention of a trademark, proprietary product, or vendor is for identification only and does not constitute a guarantee or warranty of the product by the U.S. Department of Agriculture. The U.S. Department of Agriculture prohibits discrimination in all its programs and activities on the basis of race, color, national origin, gender, religion, age, disability, political beliefs, sexual orientation, and marital or family status.

${ }^{1}$ Corresponding author. E-mail: John.Beaulieu@ars.usda.gov. and 2012, the majority of which occurred in 2006 (Campbell, 2012). As of 2012 , the Louisiana citrus industry involved $\approx 400$ growers who produced roughly 600 acres for an estimated gross farm value of almost $\$ 5.2$ million, consisting mostly $(67.7 \%)$ of satsuma (Louisiana State University AgCenter, 2012).

The historical lineages, literature, and nomenclature are confused as a result of generations of hybridism and apomixes in sexually compatible Citrus and related genera in several commercial Citrus species. The progenitors of many highly related commercial sweet, orange-fleshed Citrus species are generally believed to be $C$. reticulata, often called mandarin oranges (Mabberley, 1997; Swingle and Reece, 1967). DNA studies have confirmed the close proximity and relationships among the four types mentioned herein (clementine, mandarin, satsuma, and tangerine) as C. reticulata (de Araujo et al., 2003; Nicolosi et al., 2000). This terminology is perpetuated by several papers and consistent according to a "lumping classification" (Swingle and Reece, 1967) as opposed to a "splitters" nomenclature using confusing clades and alternate species names (e.g., C. clemintina for clementine, C. unshiu for satsuma, and C. tangerina for tangerine) (Tanaka, 1977). Recently, scientists have also lumped together common and/ or important volatiles observed and sensory attributes in these highly related Citrus species into what is termed a "consensus approach" (Miyazaki et al., 2011a; Miyazawa et al., 2010; Perez-Cacho and Rouseff, 2008b; Tietel et al., 2011). Herein, a similar consensus approach is used to view recovered volatiles in locally grown satsuma, presuming the potential aromatic 
importance of these compounds based on other author's reports, and significantly related clade designations.

To restore growth, stability, and prosperity to the Louisiana farmer, there is need to research methodologies to better understand the unique produce of Louisiana as well as develop value-added systems for processing and marketing. Juicing locally produced satsuma could become a viable alternative to diminish crop losses and boost a struggling industry. Tactics are already underway regarding redevelopment of local gulf region satsuma markets (Campbell et al., 2008). To facilitate local incentive and industry support through reducing production costs, initial juicing trials were performed at the Agricultural Research Service pilot plant using only a fruit press, enzymatic treatments, and an ultrafiltration (UF) unit. The objective was to assess the viability of rapidly producing not-from-concentrate (NFC) satsuma juice from locally grown fruit without traditional commercial peelers, juice/pulp vs. oil separation, depulping, finishers, evaporators, essence recovery machinery, and pasteurization. Simple filtration and enzyme treatments combined with rapid subjective and volatile methods were used to likewise facilitate prompt decision-making during processing.

\section{Materials and Methods}

HARVest, PREssing, AND JUICING. Commercially ripe satsuma fruit was harvested in Plaquemines, Parish LA, sorted, graded, not waxed, boxed, and transported the day of harvest to the U.S. Department of Agriculture (USDA) laboratory in New Orleans, LA. The fruit was used immediately on receipt or after shortterm (maximum $2 \mathrm{~d}$ ) storage at $8^{\circ} \mathrm{C}$. Unblemished fruit were selected and washed in $100 \mathrm{~mL} \cdot \mathrm{L}^{-1}(\mathrm{v} / \mathrm{v}) \mathrm{NaOCl}$ followed by a chilled deionized ice water bath and air-dried. Whole fruit as well as carefully hand-peeled fruit were rapidly juiced in a food-grade pilot plant by hydraulic single-layer pressing on a fruit and vegetable press (X-1; Goodnature, Orchard Park, NY) at $12,411 \mathrm{kPa}$ using medium weave, polyester mesh press bags (\#2636; Goodnature). Full bags of whole or peeled fruit $(\approx 8 \mathrm{~kg})$ were pressed in triplicate on each sampling date, and four lots of fruit used in analysis have been labeled in tables as A, B, C, and D. In general, whole-pressed fruit delivered $\approx 55.5 \%$ juice recovery and recovery increased to $\approx 66.6 \%$ in peeled pressed fruit.

Pilot Plant ultrafiltration. UF of whole-pressed juice (WPJ) as NFC was performed on a pilot filtration unit (BRO/ BUF; Membrane Specialists, Hamilton, $\mathrm{OH}$ ). The unit consists of an inline membrane filtration module (PCI B-1 Module Series; Aquious PCI Membrane, Hamilton, $\mathrm{OH}$ ) fed by a $5.59-\mathrm{kW}$ pump. The inline filter module has 18 filter elements, $1.2 \mathrm{~m}$ in length, with a total filtration area of $0.864 \mathrm{~m}^{2}$. This setup delivers $\approx 1 / 4$ to $1 / 2$ the linear distance $(21.6 \mathrm{~m})$ often encountered in commercial filtration operations with an 18.9 to $29.9 \mathrm{~L} \cdot \mathrm{min}^{-1}$ flow rate. Filtration occurred with a 200,000 molecular weight $(\mathrm{MW})$ cutoff $(0.2 \mu \mathrm{m})$ polyvinylidene fluoride membrane (XP-201; ITT PCI Membrane Systems, Zelienople, PA) with the heat exchanger run at ambient $\left(\approx 25^{\circ} \mathrm{C}\right)$ with an approximate inlet and outlet pressure of 620.5 and $137.9 \mathrm{kPa}$, respectively. After performing clean-in-place, per manufacturers' recommendations with both an acidic and basic cleanser (Ultracil 75 and Ultracil 11, respectively; Ecolabs, St. Paul, MN), the system was drained of all residual pump volume and membrane water volume was displaced by juice. Retentate was circulated from the 100 -L feeding hopper tank through the system with comparison of the initial juice color and soluble solids concentration (SSC) to the filtered permeate exiting the product port for roughly $20 \mathrm{~min}$. A digital refractometer (PR101; ATAGO, Tokyo, Japan) with readout precision of $0.1 \%(\mathrm{v} / \mathrm{v})$ was used to measure the SSC. After running in filtration mode an additional $20 \mathrm{~min}$, UF NFC satsuma juice was collected for volatile sampling.

ENZYME TREATMENTS. Immediately after pressing the freshly squeezed juices, 1-L subsamples were subjected to various enzyme treatments with constant stirring on a magnetic stir plate at concentrations according to the manufacturer. Enzymes selected (AB Enzymes, Plantation, FL) were used to act on pectin, cellulose, protein, oil separation, and bitterness, astringency, or both. These were Rohapect ${ }^{\circledR} 10 \mathrm{~L}(100 \mathrm{~mL} / 1000 \mathrm{~L})$, a standard pectinase mash enzyme for acidic apples (Malus $\times$ domestica) and berries; Rohapect ${ }^{\circledR}$ VR-C (30 g/1000 L), a red wine mash enzyme containing pectolytic, proteolytic, and cellulytic activities for ultra, osmosis filtration, and debittering; Rohapect $^{\circledR}$ PTE100 (7 mL/1000 L), an endopectinlyase activity that is generally used for citrus cloud stability and pulp wash; and Rohapect ${ }^{\circledR}$ DA6L $(50 \mathrm{~mL} / 1000 \mathrm{~L})$, a pectinase used to help the efficiency of oil recovery and removal in citrus through mechanical/centrifugal.

Juice StORAge AND EVAluation. On 0 and $7 \mathrm{~d}$, NFC juices were sampled after storage at $4{ }^{\circ} \mathrm{C}$ in sterilized $250-\mathrm{mL}$ glass bottles and held in the dark. Qualitative measurements consisted of a subjective odor and taste appraisal including visual sedimentation (Table 1), color, $\mathrm{pH}, \mathrm{SSC}$, titratable acidity (TA), SSC:TA ratio, and headspace (HS) volatiles, as described below. Subjective appraisals were performed by three trained food scientists with sensory attribute experience and consisted of overall color (loss orange), oil surface and content, smell/ aroma, sweetness, bitterness (taste on the tongue stimulated by solutions of caffeine or quinine, generally as a result of low MW compounds less than 500), astringency [a chemical feeling on the tongue described as puckering/drying, associated with tannins, generally MW greater than 500 (Drewnowski and Gomez-Carneros, 2000)], sourness (taste associated with acids like acetic or citric), sedimentation and separation of serum, pulp, and cloud. Natural sedimentation during refrigeration, without centrifugation, was used to subsample serum as well as the combined pulp and cloud. TA was measured by an automated titrator (Titrando 836; Metrohm, Riverview, FL) in $10 \mathrm{~mL}$ juice by titrating to $\mathrm{pH} 8.1 \mathrm{using} 0.1 \mathrm{~mol} \cdot \mathrm{L}^{-1}$ sodium hydroxide $(\mathrm{NaOH})$, expressed as percentage citric acid (wt/wt). $\mathrm{pH}$ was measured by an automated titrator (Titrando 836) in $10 \mathrm{~mL}$ juice. Color was measured with a chroma meter (CR400; Konica Minolta, Ramsey, NJ) in $20 \mathrm{~mL}$ juice placed in a glass 20-mL petri dish, covered with a black lid, and was analyzed with SpectraMagic software (NX lite; Konica Minolta).

Juice PARTITIONING, CONCENTRATING, AND RECONSTITUTED JUICE. Satsuma fruit was hand-peeled and hydraulically pressed and NFC juice volatiles were sampled immediately; then juices were placed in the refrigerator $\left(4^{\circ} \mathrm{C}\right)$ overnight to allow natural settling to occur and to minimize the action of pectin methylesterases (Baker and Bruemmer, 1969; Versteeg et al., 1980). The next day, equal volumes of volatile samples were withdrawn from the opaque top serum layers and the lower sedimentation layers of pulp and cloud. Juices were also vigorously shaken to reconstitute and 1-L aliquots were added to a round-bottomed flask that was connected to an evaporator (Rotavapor R-215; Buchi, Flawil, Switzerland) with vacuum 
Table 1. Subjective parameters used to evaluate Louisiana-grown not-from-concentrate fresh satsuma juices on a three-point hedonic scale.

\begin{tabular}{|c|c|c|c|}
\hline \multirow[b]{2}{*}{ Parameter } & \multicolumn{3}{|c|}{ Hedonic scale $^{z}$} \\
\hline & 3 & 2 & 1 \\
\hline Overall color (loss orange) & $\begin{array}{l}\text { Very bright orange, fresh } \\
\text { "normal"-appearing }\end{array}$ & $\begin{array}{l}\text { Visibly more pale } \\
\text { color, orange loss: } \\
\text { consumer may notice }\end{array}$ & $\begin{array}{l}\text { Severely pale "washed-out" } \\
\text { opaque looking }\end{array}$ \\
\hline Oil surface and content & None to exceedingly minor & Moderate & Severe, sticks to container \\
\hline Smell/aroma & Normal, characteristically strong (great) & $\begin{array}{l}\text { An "off-odor" exists, } \\
\text { but still acceptable } \\
\text { to taste and drink }\end{array}$ & $\begin{array}{l}\text { Off-odors so strong that the } \\
\text { juice bothers you: "sulfurous" } \\
\text { or "fermented-like" }\end{array}$ \\
\hline Sweetness & Very sweet, pleasant & Mediocre & Not sweet; bland \\
\hline $\begin{array}{l}\text { Bitterness (MW less } \\
\text { than } 500)^{\mathrm{y}}\end{array}$ & None, very fresh and "normal"-tasting & Mild & Excessively bitter \\
\hline $\begin{array}{l}\text { Astringency (MW greater } \\
\text { than } 500)^{\mathrm{x}}\end{array}$ & None, very fresh and "normal"-tasting & Mild & Excessively astringent \\
\hline Sourness ${ }^{\mathrm{w}}$ & None, very fresh and "normal"-tasting & Mild & Excessively sour \\
\hline
\end{tabular}

z 3 = optimum or acceptable, 2 = minimum score (limit) for marketability, 1 = unacceptable and unmarketable.

${ }^{y}$ Bitterness is one of the four basic tastes. A major source of bitterness is the tannin content. Attribute examples would be black coffee, quinine, and bittersweet chocolate. Molecular weight (MW) differentiation per Drewnowski and Gomez-Carneros (2000).

${ }^{\mathrm{x}}$ Astringency is a chemical feeling on the tongue described as puckering/dry associated with strong tea; a rough, puckering taste, usually attributed to very high tannin content.

wSourness is one of the four basic tastes. Acidic is a synonym that implies presence of acetic acid plus excess acids.

pulled to $8 \mathrm{kPa}$ while gently heating in a warm water bath at $60^{\circ} \mathrm{C}$ and rotating at $170 \mathrm{rpm}$ overnight. The resulting satsuma essence (water condensate) was sampled the next morning after concentrating the juice to an industry standard $\approx 65 \%$ SSC $(58.3 \%, 69.5 \%$, and $67.3 \%$ SSC). Recovery of volatile compounds remaining in the concentrated juice was determined after reconstituting back to $10.5 \%$ SSC (average fruit SSC of this lot) with pure water approximating the related citrus standard for $100 \%$ single strength orange (C. sinensis) and tangerine juice (11.8\%) per U.S. Code of Federal Regulation (U.S. Food and Drug Administration, 2011).

GC/MS VolatiLE ANALYSIS. Volatile samples were prepared in triplicate from each pressed juice from whole or peeled satsuma, subsequent enzymatic and storage treatments, and partitioned samples. Sample vials $(20 \mathrm{~mL})$ with $1 \mathrm{~mL}$ juice plus $9 \mathrm{~mL}$ deionized nanopure water, $2.2 \mathrm{~g}$ of $\mathrm{NaCl}$, and a $100-\mu \mathrm{L} \cdot \mathrm{L}^{-1}$ final concentration internal standard of 2-nonanone were equilibrated $10 \mathrm{~min}$ by oscillation in a $35^{\circ} \mathrm{C}$ autosampler (MPS2 XL; Gerstel, Baltimore, MD). HS was exposed to $1-\mathrm{cm}$ polymercoated, divinylbenzene carboxen polydimethylsiloxane solidphase microextraction (SPME), fused $50 / 30-\mu \mathrm{m}$ triple fibers (StableFlex; Supelco, Bellefonte, PA) for $15 \mathrm{~min}$ at $65^{\circ} \mathrm{C}$. Vials were continuously swirled during SPME adsorption with an agitation speed of $750 \mathrm{rpm}$ before injection into a gas chromatography-mass spectrometry [GC/MS (HP6890/5973; Agilent Technologies, Santa Clara, CA)] with a crosslinked 5\% phenyl methyl silicone column, $30 \mathrm{~m} \times 0.25 \mathrm{~mm} \times 0.25-\mu \mathrm{m}$ film thickness (HP-5; Agilent Technologies). The injection port was operated in splitless mode and subjected to a pulse pressure of $415 \mathrm{kPa}$ of ultrahigh purity helium $(99.9995 \%)$ for the first minute; then flow velocity was constant at $35 \mathrm{~cm} \cdot \mathrm{s}^{-1}$ for the remainder of the $\mathrm{GC}$ run. The initial oven temperature was 40 ${ }^{\circ} \mathrm{C}$, held $1 \mathrm{~min}$, increased $5^{\circ} \mathrm{C} \cdot \mathrm{min}^{-1}$ to $110^{\circ} \mathrm{C}$ then $10^{\circ} \mathrm{C} \cdot \mathrm{min}^{-1}$ to $150{ }^{\circ} \mathrm{C}$, and held $9 \mathrm{~min}$. The HP5973 quadrupole MS was operated in the electron ionization mode at $70 \mathrm{eV}$ at $200{ }^{\circ} \mathrm{C}$ with a continuous scan from 33 to 300 mass to charge ratio $(\mathrm{m} / \mathrm{z})$. Cryofocussing $\left(-60{ }^{\circ} \mathrm{C}\right)$ at the GC inlet was used as compounds were desorbed $(1 \mathrm{~min})$ from the SPME fiber atop the column. Commercial-like pasteurized pilot plant juice samples [one anonymous manufacturer, product lot labeled: $10.09 \% \mathrm{SSC}, 0.49 \% \mathrm{TA}$ as citric acid (wt/wt) and SSC:TA ratio 20.6] was analyzed by the identical methods aforementioned, repeated several times, using SPME. Juices were stored and held according to how they were handled by the pilot plant (e.g., frozen at $-20{ }^{\circ} \mathrm{C}$ in polyethylene terephthalate containers).

VOLATILE DATA PROCESSING. Volatile MS data were collected with HP ChemStation software (A.03.00; Agilent Technologies) and searched against the Wiley7th/NIST02 registry of mass spectral data (McLafferty, 2000). Compounds were preliminarily identified by library search; then their identity was confirmed by standard comparisons (see below), GC retention time (RT), MS ion spectra, and an in-house retention index (RI) per Table 2. High purity GC/MS grade (greater than $99.5 \%$ purity) standards used to identify compounds in juice samples were purchased from commercial sources: \{Aldrich Chemical Co. [Milwaukee, WI]; Bedoukian Research [Danbury, CT]; Berje [Carteret, NJ]; Fisher [Pittsburgh, PA]; Fluka [Buchs, Switzerland (now Sigma-Aldrich, St. Louis, MO)]; J.T. Baker [Phillipsburg, PA]; Sigma [Sigma-Aldrich]; and Sigma-Aldrich Fine Chemicals [SAFC, St. Louis, MO]\} according to Table 2. The averaged RT from a triplicate series of straight chain alkanes $\left(\mathrm{C}_{5}-\mathrm{C}_{19}\right)$ were used to calculate relative RIs for standards, identified, and tentative compounds. A suite of 44 compounds in satsuma samples was integrated and analyzed. Similar to an approach where the literature dictated the probable, consensus mandarin compounds of flavor/aroma importance (Tietel et al., 2011), integrated ion abundance data for 19 compounds were normalized on the internal standard, per replicate, averaged, and tabled. 
Table 2. Volatile compounds qualitatively recovered by headspace solid phase microextraction using divinylbenzene carboxen polydimethylsiloxane fibers and gas chromatography-mass spectrometry in Louisiana-grown satsuma.

\begin{tabular}{|c|c|c|c|c|c|}
\hline$\overline{\text { Compound }}$ & Standard $^{\mathrm{z}}$ & $\mathrm{RT}^{\mathrm{y}}$ & $\mathrm{RI}^{\mathrm{x}}$ & $\mathrm{MW}^{\mathrm{w}}$ & $\mathrm{CAS}^{\mathrm{v}}$ \\
\hline Acetaldehyde & $\mathrm{S}$ & 0.45 & 479 & 44.052 & $75-07-0$ \\
\hline 1-pentanol & $\mathrm{F}$ & 2.43 & 797 & 88.148 & $71-41-0$ \\
\hline Hexanal & A & 3.54 & 869 & 100.159 & $66-25-1$ \\
\hline (E)-2-hexenal & A & 5.42 & 884 & 98.143 & $6728-26-3$ \\
\hline 3-heptanone & - & 6.54 & 898 & 114.186 & $106-35-4$ \\
\hline Heptanal & A & 7.03 & 908 & 114.186 & $111-71-7$ \\
\hline$\alpha$-phellandrene & $\mathrm{S}$ & 7.84 & 922 & 136.234 & $99-83-2$ \\
\hline$\alpha$-pinene & A & 8.04 & 928 & 136.234 & $80-56-8$ \\
\hline $\begin{array}{l}\text { 4-methyl-2- } \\
\text { heptanone }\end{array}$ & - & 8.25 & 935 & 128.212 & $6137-06-0$ \\
\hline$\beta$-pinene & A & 9.44 & 970 & 136.234 & $127-91-3$ \\
\hline$\beta$-myrcene & $\mathrm{S}$ & 9.91 & 984 & 136.234 & $123-35-3$ \\
\hline Octanal & $\mathrm{S}$ & 10.33 & 997 & 128.212 & $124-13-0$ \\
\hline$\alpha$-terpinene & A & 10.74 & 1010 & 136.234 & $99-86-5$ \\
\hline$p$-cymene & A & 10.98 & 1017 & 134.218 & $99-87-6$ \\
\hline Limonene & Fl & 11.10 & 1021 & 136.234 & $138-86-3$ \\
\hline$\gamma$-terpinene & A & 12.04 & 1051 & 136.234 & $99-85-4$ \\
\hline 1-octanol & JTB & 12.43 & 1063 & 130.228 & $111-87-5$ \\
\hline$\alpha$-terpinolene & $\mathrm{Fl}$ & 12.95 & 1079 & 136.230 & $586-62-9$ \\
\hline 2-nonanone (IS) & A & 13.06 & 1083 & 142.239 & $821-55-6$ \\
\hline Linalool & A & 13.30 & 1090 & 154.249 & $78-70-6$ \\
\hline Nonanal & A & 13.45 & 1095 & 142.239 & $124-19-6$ \\
\hline$\beta$-terpineol & - & 14.70 & 1139 & 154.250 & $138-87-4$ \\
\hline 4-terpineol & SAFC & 15.60 & 1171 & 154.250 & $562-74-3$ \\
\hline$\alpha$-terpineol & A & 15.95 & 1183 & 154.250 & $98-55-5$ \\
\hline Decanal & $\mathrm{S}$ & 16.31 & 1196 & 156.265 & $112-31-2$ \\
\hline Octyl acetate & A & 16.44 & 1201 & 172.265 & $112-14-1$ \\
\hline 2,4-decadienal & B & 16.62 & 1210 & 152.233 & $2363-88-4$ \\
\hline$(E)$-carveol & A & 16.64 & 1211 & 152.233 & $1197-07-5$ \\
\hline$\beta$-citronellol & B & 16.82 & 1219 & 156.270 & $106-22-9$ \\
\hline$(Z)$-citral & 一 & 17.14 & 1235 & 152.233 & $106-26-3$ \\
\hline Carvone & 一 & 17.23 & 1239 & 150.218 & $99-49-0$ \\
\hline$(E)$-geraniol & B & 17.39 & 1247 & 154.249 & $106-24-1$ \\
\hline$(E)$-citral & - & 17.74 & 1263 & 152.233 & $141-27-5$ \\
\hline Perillaldehyde & 一 & 17.85 & 1269 & 150.218 & $2111-75-3$ \\
\hline$\delta$-elemene & 一 & 19.02 & 1331 & 204.360 & $20307-84-0$ \\
\hline Neryl acetate $(Z)$ & A & 19.42 & 1355 & 196.290 & $141-12-8$ \\
\hline Geranyl acetate $(E)$ & - & 19.75 & 1375 & 196.286 & $105-87-3$ \\
\hline$\beta$-damascenone & $\mathrm{Bj}$ & 19.80 & 1378 & 190.280 & $23726-93-4$ \\
\hline$\beta$-elemene & - & 19.94 & 1386 & 204.351 & $515-13-9$ \\
\hline Dodecanal & - & 20.13 & 1397 & 184.318 & $112-54-9$ \\
\hline$\beta$-caryophellene & $\mathrm{F} 1$ & 20.41 & 1420 & 204.350 & $87-44-5$ \\
\hline$\gamma$-elemene & - & 20.52 & 1430 & 204.350 & 29873-99-2 \\
\hline (E)-geranyl acetone & $\mathrm{B}$ & 20.71 & 1447 & 194.313 & $3796-70-1$ \\
\hline (Z)-alpha bisabolene & - & 20.84 & 1458 & 204.350 & $29837-07-8$ \\
\hline Valencene & SAFC & 21.24 & 1493 & 204.351 & $4630-17-3$ \\
\hline
\end{tabular}

${ }^{\mathrm{z}}$ Authentic standards used for compound confirmation obtained from: $\mathrm{A}=$ Aldrich Chemical Co. (Milwaukee, WI), B = Bedoukian Research (Danbury, CT), Bj = Berje (Carteret, NJ), F = Fisher (Pittsburgh, PA), $\mathrm{Fl}=$ Fluka [Buchs, Switzerland (now Sigma-Aldrich, St. Louis, MO)], JTB = J.T. Baker (Phillipsburg, PA), S = Sigma-Aldrich, SFAC = Sigma-Aldrich Fine Chemicals, $-=$ standard not acquired.

${ }^{\mathrm{y}} \mathrm{RT}=$ retention time on a crosslinked $5 \%$ phenyl methyl silicone column (HP-5; Agilent Technologies, Santa Clara, CA).

${ }^{\mathrm{x}} \mathrm{RI}=$ retention index.

${ }^{\mathrm{w}} \mathrm{MW}=$ molecular weight.

${ }^{\mathrm{v}} \mathrm{CAS}=$ Chemical Abstracts Service (Columbus, OH) number.
EXPERIMENTAL DESIGN. A complete randomized block design was used with three replicates for all analyses from each batch of fruit (A, B, C, and D), including three controls for every batch of freshly pressed fruit. Data were subjected to a two-way analysis of variance (ANOVA) using general linear model procedures. When needed, data were transformed into log 10 to fit normal distribution before being subjected to ANOVA using JMP (Version 5.1.2 for Windows; SAS Institute, Cary, NC). To study the effect of each enzyme, values were compared with the respective control by the Dunnett contrast at $P \leq 0.05$. To study differences between enzyme treatments, data were subjected to ANOVA and the significance among treatments was assessed using the Tukey test at $P \leq 0.05$.

\section{Results and Discussion}

Using StableFlex triple-fiber SPME, several previously reported citrus compounds (44) were recovered in Louisianagrown satsuma juices throughout a single growing season (Table 2). From the 44 compounds, 31 were positively identified with standards, whereas the remaining 13 were tentatively identified based on MS ion fragmentation pattern, library matches, and comparison with RI data in the literature. Volatile samples analyzed herein were diluted 10 -fold compared with the normal SPME method. This was the result of processing whole unpeeled fruit and because total volatiles in mechanically squeezed juices are three to 10 times greater than hand-squeezed juices as a result of elevated peel oil levels (Perez-Cacho and Rouseff, 2008b), and satsuma peels contain significant levels of peel oils (Choi, 2004). With this rapid volatile extraction method, 23 terpenoids, 12 aldehydes, three esters, three alcohols, and three ketones were recovered.

The citrus industry has been altering processing methods to efficiently produce several citrus juices and assessing flavor and quality for decades (Bai et al., 2011; Jordan et al., 2003; Miyazaki et al., 2011a, 2011b; Morris, 2010; Perez-Cacho and Rouseff, 2008a, 2008b; Plotto et al., 2004, 2008, 2010; Rouseff et al., 2009; Shaw, 1991; Shaw and Moshonas, 1993; Traub et al., 1932). Flavor impact and other compounds of interest reported in satsuma and closely related Citrus species were used to guide quality assessments (Barboni et al., 2009; Choi, 2004; Elmaci and Altug, 2005; Miyazaki et al., 2011a, 2011b; Miyazawa et al., 2010; Moshonas and Shaw, 1997; Perez et al., 2005; Tietel et al., 2011; Traub et al., 1932). SPME has been extensively applied to the study of orange and citrus juice aroma (Bazemore et al., 1999; Jia et al., 1998; Jordan et al., 2005; Miller and Stuart, 1998; Miyazaki et al., 2011a, 2011b; Rega et al., 2003; Steffen and Pawliszyn, 1996). An optimized and/or ideal SPME method should absorb all analytes nonselectively; however, reports indicate SPME is selective with a limited capacity (Bazemore et al., 1999; Rega et al., 2003; Yang and Peppard, 1994). The authors are aware that many important citrus volatiles and peel oils have been extracted in the past with solvents and such methods tend to recover low volatility and oil soluble compounds such as methyl Nmethylanthranilate (MNMA), $\alpha$-sinensal, and $\beta$-damascenone, which may be missed when using HS techniques (Perez et al., 2005). For example, MNMA has been reported to be an important peel odorant in mandarin (Wilson and Shaw, 1981) and satsuma (Elmaci and Altug, 2005). However, because anthranilates are often not reported or only recovered in trace amounts in satsuma and mandarin (Choi, 2004; Miyazaki et al., 2011a; 


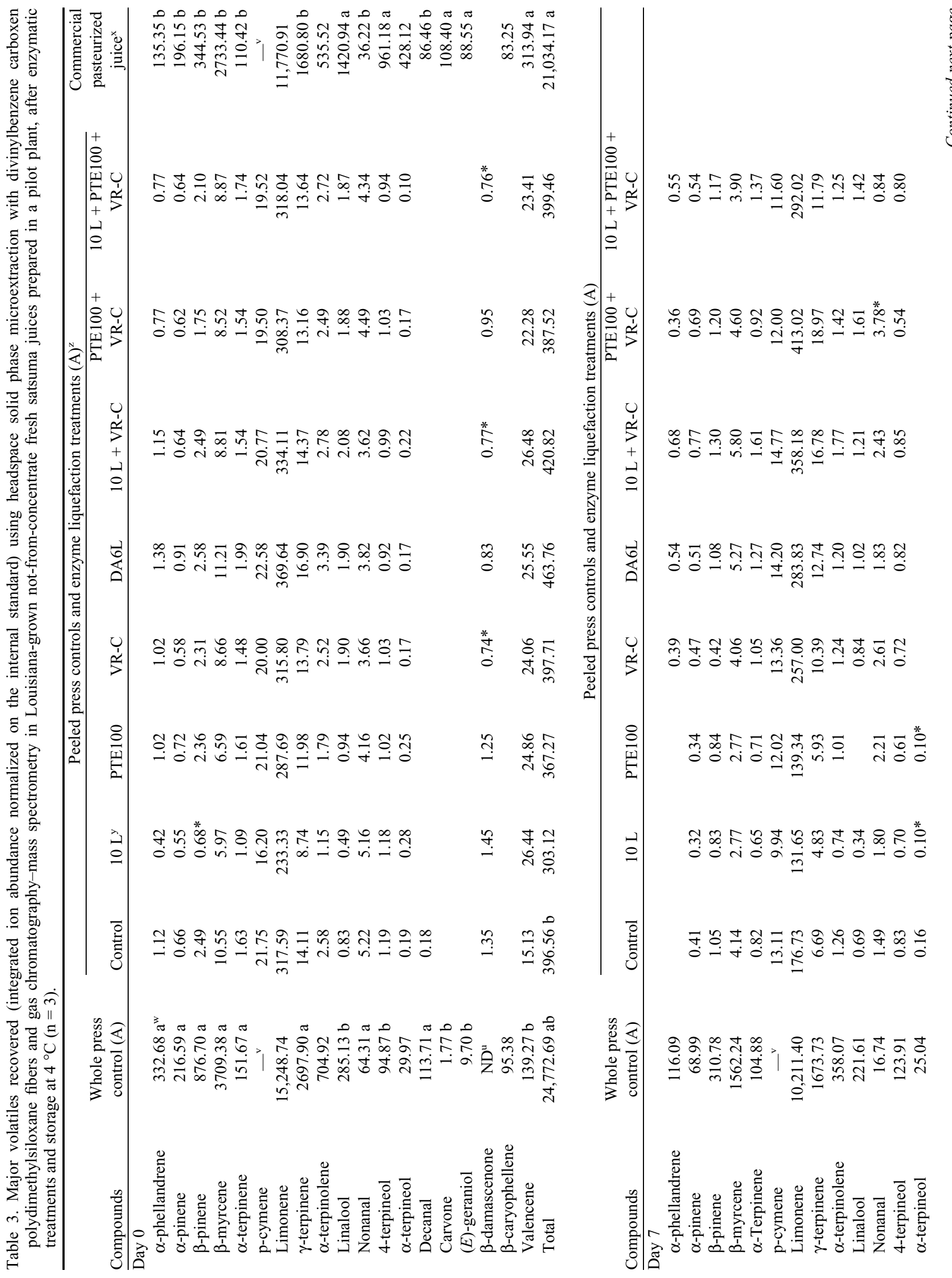




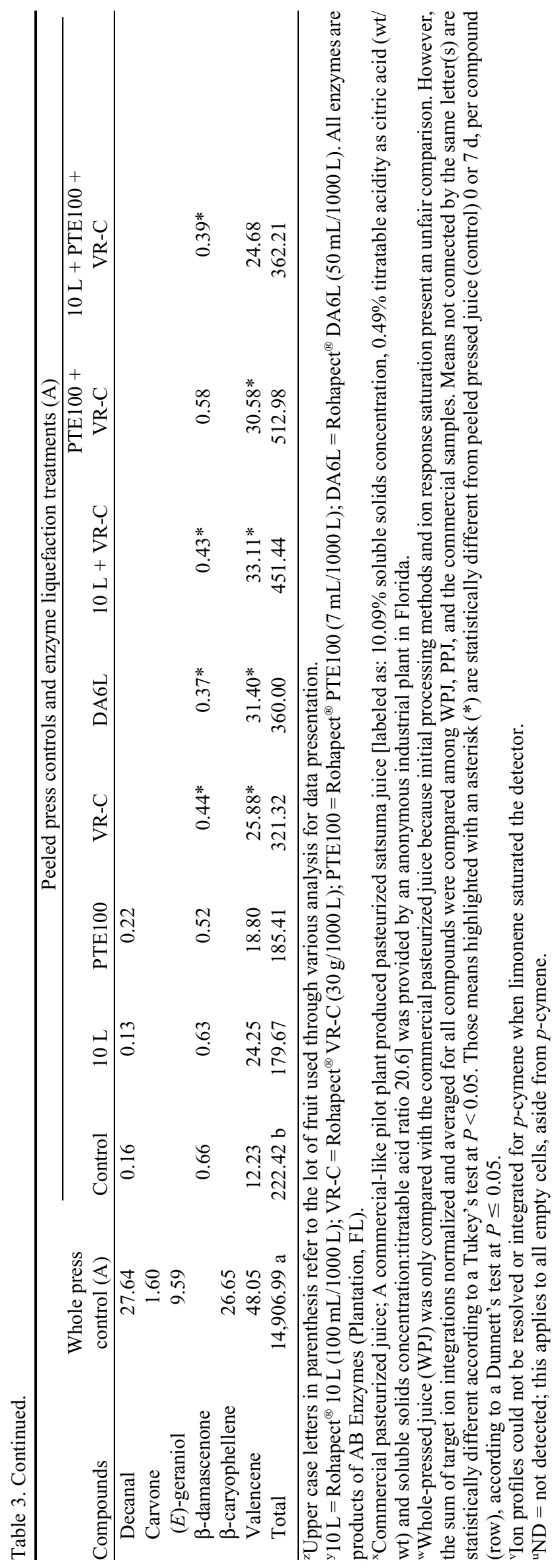

Miyazawa et al., 2010), isolation in PPJ was not attempted. On the other hand, $\beta$-damascenone was recovered in all PPJ samples (Tables 3 and 4). Congruent with the objectives, this set of data is considered a qualitative, not quantitative assessment with a goal of rapidly producing a freshly squeezed local satsuma juice.

Juice STORAge AND volatile EVALUation. A suite of 19 compounds was used to evaluate pilot plant produced NFC satsuma juices (Table 3 and 4). Most of these compounds have been reported in several satsuma articles and also corroborate well with other closely related C. reticulata (Choi, 2004; Elmaci and Altug, 2005; Miyazawa et al., 2010; Moshonas and Shaw, 1997; Qiao et al., 2007; Yajima et al., 1979). (E)ocimene, hexanal, $(E)$-3-hexenal, and carveol were occasionally recovered, most often in juices from whole fruit, but inconsistency or integration errors precluded using the data. Overall, the suite of compounds herein was based on two main criteria. Primarily, compounds recovered and illustrated are similar in nature to a likely suite of consensus aroma/flavor compounds in mandarin oranges, as previously published (Tietel et al., 2011). For example, herein are included all eight consensus compounds $(\alpha$-pinene, $\beta$-myrcene, limonene, linalool, nonanal, 4-terpineol, $\alpha$-terpineol, and decanal) previously recovered in mandarin orange (Tietel et al., 2011). These authors point out that there is a lack of published consumer studies to explain specific parameters such as volatiles and aroma for mandarins, and there are even fewer studies for satsuma. Second, compounds presented were generally observed after pressing both peeled and unpeeled fruit. It is well known that citrus peel oils are responsible for an appreciable amount of volatiles that are highly important regarding qualitative and quantitative flavor/aroma appraisals (Baldwin et al., 2012). Nonetheless, the absolute quantity of a given volatile does not necessarily indicate their contribution to overall aroma (Buettner and Schieberle, 2001). For example, fewer than 25 of the more than 300 volatile compounds reported from GC/MS studies on fresh orange juice confer significant odor activity based on their endogenous levels (Perez-Cacho and Rouseff, 2008b). These are likely logical reasons why other authors have recently focused their citrus volatile surveys on an aroma importance consensus approach instead of abundance (Miyazaki et al., 2011a; Miyazawa et al., 2010; Perez-Cacho and Rouseff, 2008b; Tietel et al., 2011). A summary of aroma attributes reported in the literature for compounds presented in this study is found in Table 5.

Limonene saturated the MS profiles in WPJ and was the dominant integrated peak in almost all PPJ, even when samples were diluted 10-fold, and it occasionally saturated the MS detector as well (Table 3). Because limonene saturated the MS response, the ChemStation software would not properly integrate based on unique Q-ions $(68,93,107)$. As a result of saturated ion profiles for limonene, usually eluting at 11.10 min, width became 11.03 to $12.00 \mathrm{~min}$. Manual integration (confirmed by Q-ion ratios) was required to generate data that was aligned with literature regarding the proportion and relevance of limonene in oranges (Tables 3 and 4). $p$-cymene $(\mathrm{RT}=10.98, \mathrm{RI}=1017$, ions $119,134,91)$ and $(E)$-ocimene $(\mathrm{RT}=12.35, \mathrm{RI}=1060$, ion data not shown) were adjacent to and/or saturated by limonene and therefore could not always be resolved as a result of similar ion profiles. Therefore, data for $p$-cymene were occasionally lost (Tables 3 and 4), and $(E)$-ocimene was not integrated. 


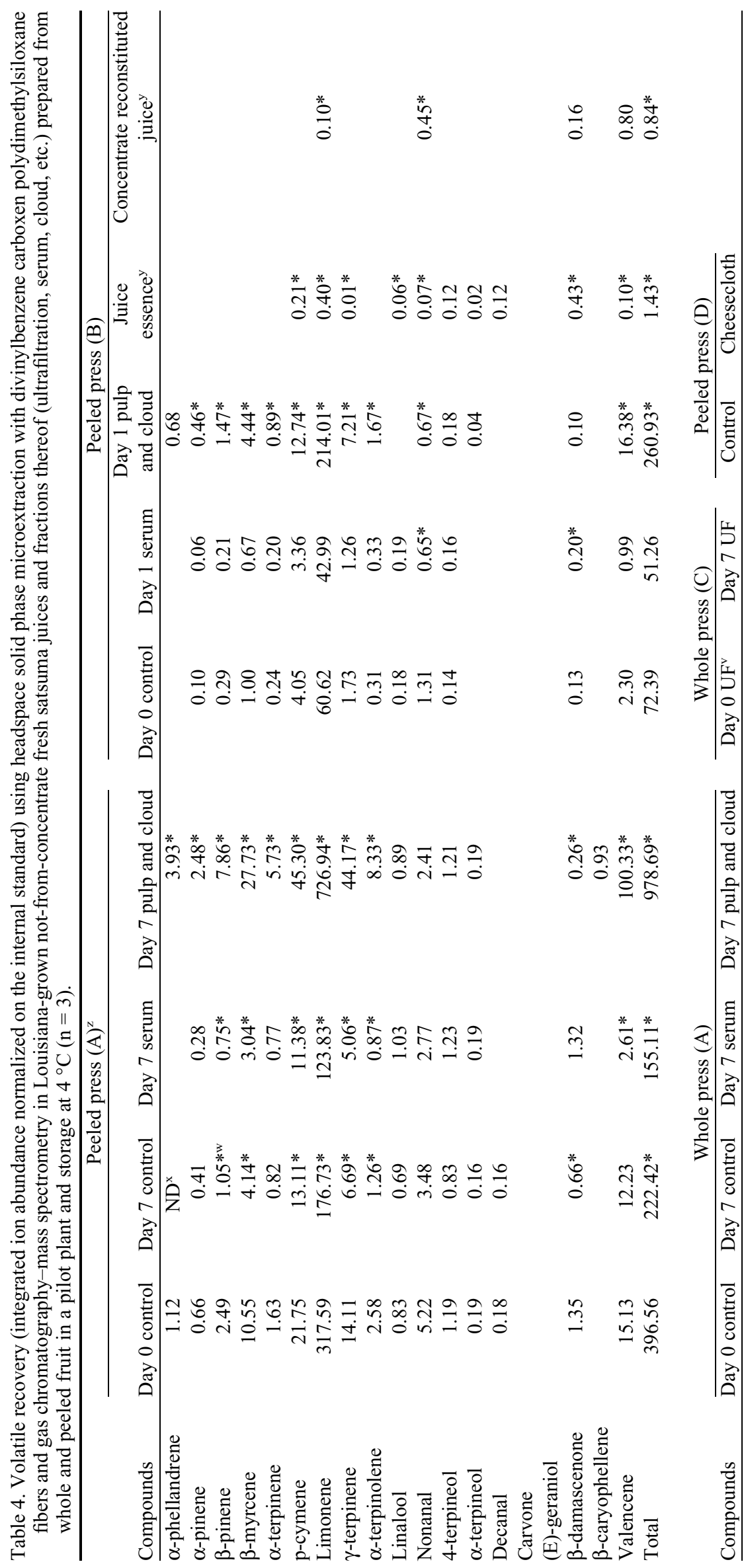

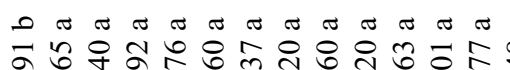

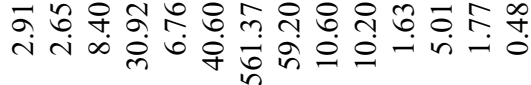

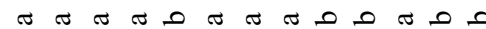

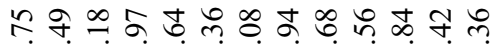

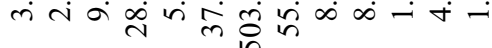

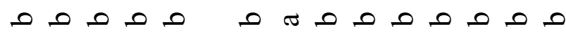
๘) $\infty$ ปn

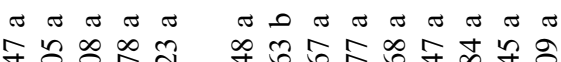

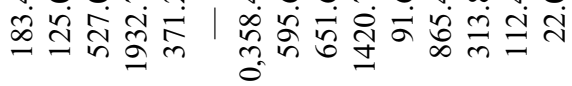

бํำ กิ तై

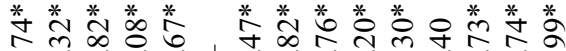
in

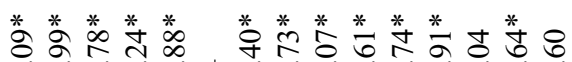

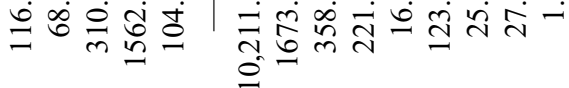

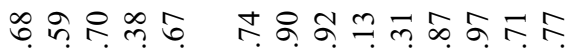
光

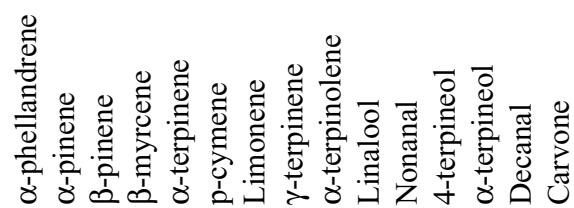




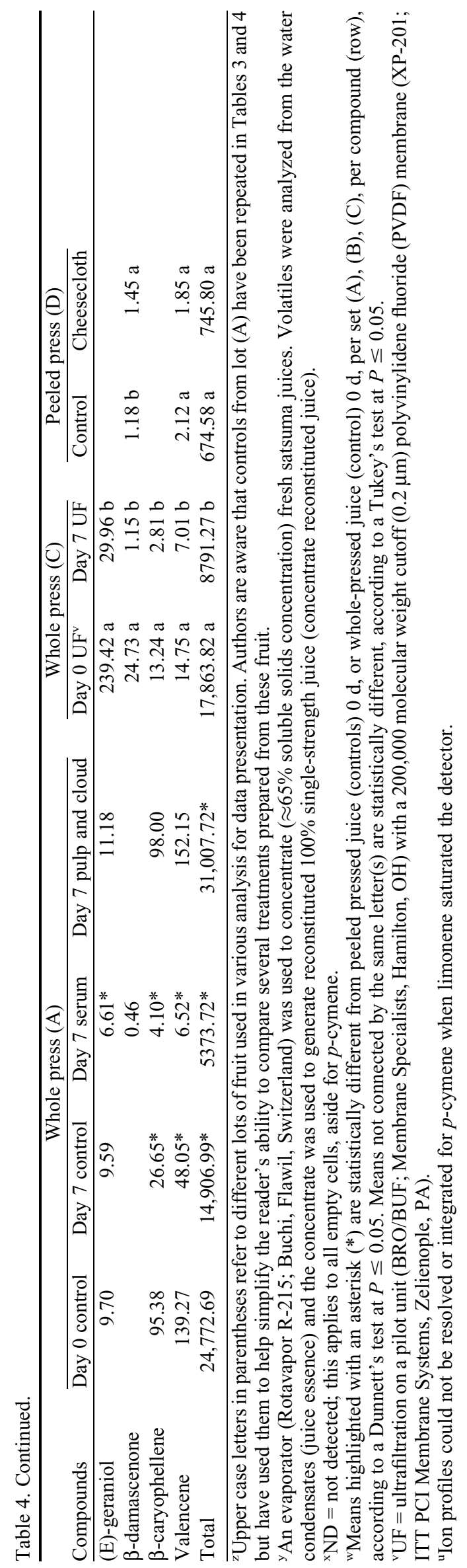

Limonene, $\beta$-myrcene, $\gamma$-terpinene, $\beta$-pinene, and $\alpha$-terpinolene were generally the most abundant peel oil related terpenoids (93.8\% of the total 19 compounds reviewed) recovered in WPJ on $0 \mathrm{~d}$ (Table 3 ). This is similar to a report indicating that $98 \%$ of the peel oil consisted of the hydrocarbons limonene, $\gamma$-terpinene, myrcene, and $\alpha$-pinene (Yajima et al., 1979). Based on the 19 compounds integrated, WPJ had $61.6 \%$ limonene that increased to $80.1 \%$ on peel removal. After 7 d storage, these levels were somewhat conserved in WPJ $(68.5 \%)$ and almost identical (79.5\%) in PPJ (Table 3). Most of the limonene comes from peel oil and is introduced into the juice during mechanical extraction, and it is the most abundant terpene hydrocarbon in orange juice (Perez-Cacho and Rouseff, 2008a), mandarin (Miyazaki et al., 2011b; Moshonas and Shaw, 1997), and satsuma (Elmaci and Altug, 2005; Moshonas and Shaw, 1997; Qiao et al., 2007). On both 0 and 7 d, WPJ also had significantly higher relative concentration of most terpenoids, especially those associated with the peel compared with PPJ (Table 3). Removal of the peel allowed for characterization of more subtle compounds such as lower MW alcohols, ketones, and terpenoids (Table 2). Superior MS resolution occurred in the peeled fruit juices, although there were still terpenoids carried over from peel, flavedo, or both. Limonene was detected in large quantities although fruit were carefully hand-peeled (Table 3).

Similar to sastuma mandarin (Choi, 2004; Elmaci and Altug, 2005; Miyazaki et al., 2011a; Qiao et al., 2007; Yajima et al., 1979), the monoterpene hydrocarbon limonene often dominated the total ion integration profiles. The citrus-like odor of limonene was not detected by GC olfactometry in some mandarin (Miyazaki et al., 2011b) and occasionally not instrumentally detected in satsuma (Miyazawa et al., 2010). Elevated peel oil content and limonene change the relative proportion of several key citrus odorants (Perez-Cacho and Rouseff, 2008b), and limonene has a high odor threshold of $13,700 \mu \mathrm{g} \cdot \mathrm{L}^{-1}$ (Plotto et al., 2004). Although reports have indicated that limonene may or may not be a reliable indicator of aroma impact in citrus, it has been considered an important carrier for other hydrophobic volatiles (Perez-Cacho and Rouseff, 2008b). Limonene was the dominant compound recovered in all stored PPJ with an average relative percentage on 0 and $7 \mathrm{~d}$ of $79.1 \%$ and $78.4 \%$, respectively (Table 3, set A) and $79.1 \%$ in additional treatments reported in Table 4 (nonrepeated set $\mathrm{A}$ and $\mathrm{B}, \mathrm{C}$ ). Data suggest it might also act as a volatile carrier in Louisiana-grown satsuma.

WPJ contained the greatest amount of total integrated volatiles, which was very comparable to a commercial-like pasteurized satsuma juice (Table 3 ). This is expected because the commercial juice industry routinely processes fruit to incorporate some peel oils or supplements pasteurized bottled products with flavor packs (natural peel oils, recovered volatile essence, or both). Peel removal resulted in significant loss (98.4\%) of the total volatiles on $0 \mathrm{~d}$, although the distribution of the volatiles remaining was not markedly different compared with WPJ (Table 3). Carvone, $(E)$-geraniol, and $\beta$-caryophellene were not present in control and enzyme-treated PPJ throughout the study (Table 3). On $0 \mathrm{~d}$ there was a $97.9 \%$ loss in limonene in the PPJ compared with the WPJ control (Table 3). Limonene and $\gamma$-terpinene accounted for $\approx 88 \%$ of the identified flavor compounds in Turkish-grown satsuma (Elmaci and Altug, 2005). Across all treatments (Tables 3 and 4), PPJ contained little to no decanal, carvone, $(E)$-geraniol, and $\beta$-caryophellene. 
Table 5. Consensus aroma impact volatiles based on literature reported for several Citrus reticulata, and predominant compounds recovered during one season in Louisiana-grown, not-from-concentrate satsuma juices.

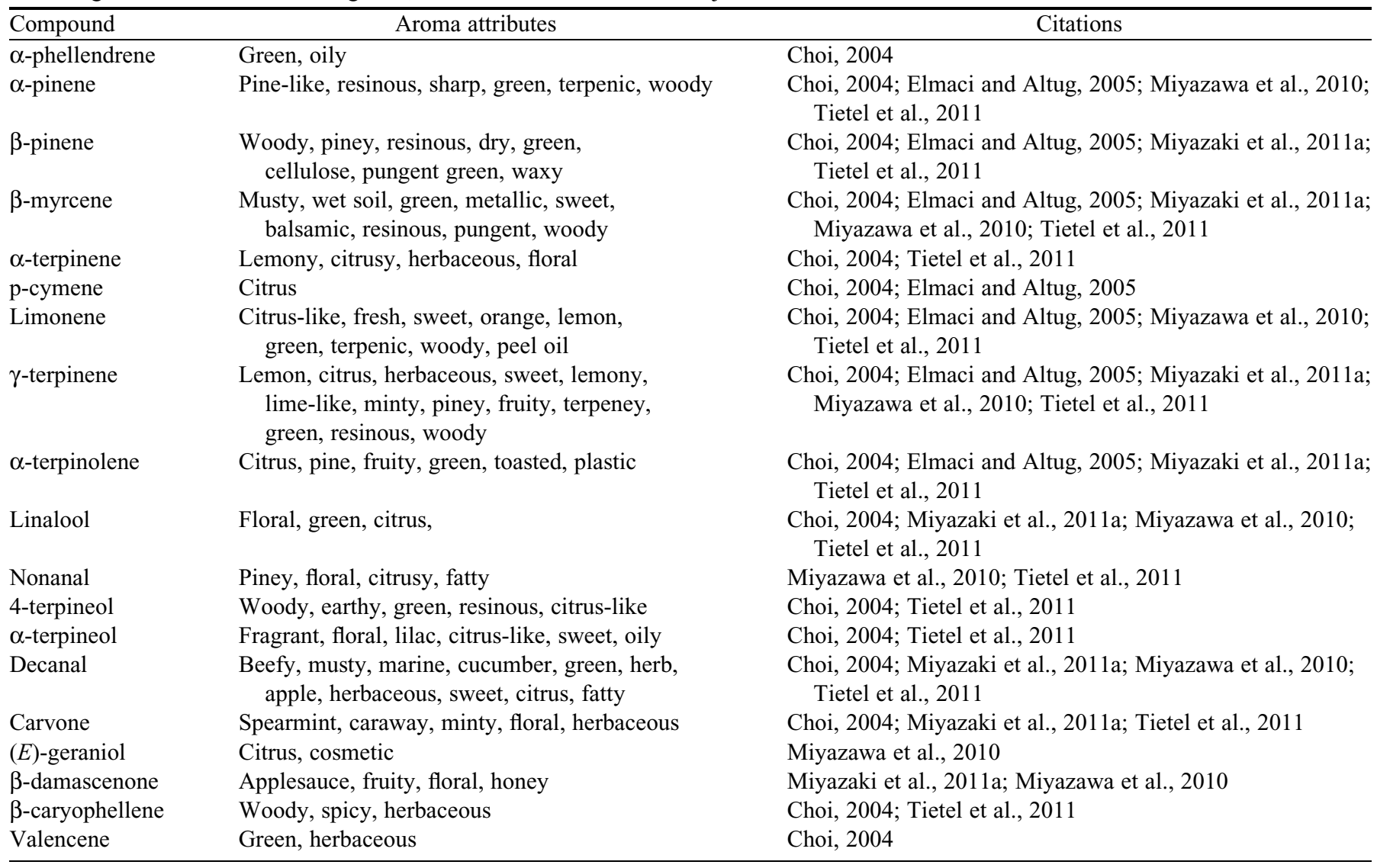

Carvone is an off-flavor ketone produced from the oxidation of limonene (Perez-Cacho and Rouseff, 2008a). One of the principal sesquiterpenes in satsuma peel oil is $\beta$-caryophellene (Choi, 2004), which was not present in peeled samples; reduced processing decreased limonene, other peel oils, and oxidation lowered decanal and carvone as well.

Pressing whole fruit on a hydraulic press delivered similar results because when fruit is juiced using commercial extractors (Barboni et al., 2009; Perez-Lopez et al., 2006), more peel oil components were present, similar to the commercial satsuma comparison (Table 3). The major peel oil volatiles in commercial orange juices are limonene, myrcene, $\alpha$-pinene, sabinene, linalool, octanal, nonanal, decanal, and sinensal, which are introduced into orange juice by mechanical juice extraction (Baldwin et al., 2012; Coleman and Shaw, 1971; Moshonas and Shaw, 1994; Shaw, 1991). Peeled fruit juice data from this study clearly indicates peel oils migrated into PPJ, because several saturated terpenes such as limonene, myrcene, $\gamma$-terpinene, $\alpha$-terpinolene, and $\beta$-pinene were observed regularly as well as other minor terpenoids (e.g., $\alpha$-phellendrene, 4-terpineol). Even careful hand extraction of the peels can introduce minor amounts of peel oil compounds into the juices (Bazemore et al., 2003), as evidenced by limonene and other terpenes in the control juices (Tables 3 and 4, sets B and D).

Enzyme treatments and volatile evaluation. Peeling and pressing fruit led to a marked reduction in almost all compounds reported in 0-d controls. Most enzyme treatments and combinations on $0 \mathrm{~d}$ resulted in no major differences compared with the control. Many of the other lower concentration volatiles (e.g., $\alpha$-pinene, $\alpha$-terpinene, $p$-cymene, $\gamma$-terpinene, $\alpha$-terpinolene, linalool, nonanal, 4-terpineol, $\alpha$-terpineol, and $\beta$-damascenone) remained at levels close to the peeled control juice on $0 \mathrm{~d}$ after enzyme treatments. There were two exceptions regarding $\beta$-damascenone and valencene. $\beta$-damascenone tended to be significantly lower in most combined enzyme treatments, and there was a slight increase on $0 \mathrm{~d}$ and a significant increase $(63.4 \%$ across treatments) in valencene after enzyme treatments by $7 \mathrm{~d}$ (Table 3 ). $\alpha$-terpineol and 4-terpineol were detected in the majority of PPJ reported (Tables 3 and 4), although they have been reported as off-flavor components resulting from heat treatments in mandarin juices (Perez-Lopez et al., 2006). Although juices we report are freshly squeezed, $p$-cymene and $\beta$-damascenone have been associated with floral and slight off-flavors in oxidized/processed orange juice (Perez-Cacho and Rouseff, 2008a).

There were generally increases in several recovered volatiles on $7 \mathrm{~d}$ for the combination enzyme treatments in PPJ, especially $10 \mathrm{~L}+\mathrm{VR}-\mathrm{C}$ and PTE100 + VR-C and then DA6L and $10 \mathrm{~L}+$ PTE100 + VR-C, yet most were insignificant (Table 3 ). Data suggest the combined effects of increased cell wall decomposition as a result of combinations of endopectinlyase, proteolytic, and cellulytic activities allowed for more volatile release during storage. Elevated levels of valencene were generally also observed after $7 \mathrm{~d}$ storage (Table 3 ). This suggests that the valencene occurring in juice oil (Shaw, 1991 ) is possibly liberated from juice sacks during enzyme cleavage and subsequent storage. $\beta$-damascenone, a carotenoid breakdown product, was stable and had a persistent presence in 
all peeled juices on 0 and $7 \mathrm{~d}$ (Table 3 ). $\beta$-damascenone was only recovered from juices when fruit were peeled and remained through $7 \mathrm{~d}$ storage, independent of enzyme treatments. Certain satsuma peel oils, like $\beta$-caryophellene (Choi, 2004), did not appear in the PPJ, except after $7 \mathrm{~d}$ storage in the pulp and cloud (Table 4).

JuiCe PARTITIONING, CONCENTRATING, RECONSTITUTED JUICE, AND FILTRATION. In addition to enzyme-treated peeled fruit juices, volatile assessment of serum, pulp and cloud, UF juice, concentrated juice (with the resulting water phase essence), and reconstituted juice was performed (Table 4). Previous studies have examined the various liquid/solid phases and distribution of proteins, volatiles, and enzymes leading to qualitative and chemical property differences in the serum, pulp, and cloud of orange juice (Baker and Bruemmer, 1969; Baldwin et al., 2012; Radford et al., 1974; Rega et al., 2004; Versteeg et al., 1980). To the best of our knowledge, this has not been accomplished in satsuma.

Data show that the total amount of volatiles was markedly different between two sets of PPJ (A and B), yet the relative distribution of terpenes and most other compounds between the serum vs. cloud and pulp was analogous (Table 4). These different juice batches, sampled at either 1 or $7 \mathrm{~d}$, compared with their respective controls followed similar trends. There was a $70.8 \%$ and $69.7 \%$ reduction in total volatiles recovered in PPJ serum from their respective shaken controls (Table 4, sets B and $\mathrm{A}$, respectively). On the other hand, volatiles recovered in the pulp and cloud in these settled PPJ increased significantly by $260.5 \%$ and $340.0 \%$ after 1 and $7 \mathrm{~d}$, respectively, compared with their shaken controls (Table 4). Set A was also sampled as WPJ and the amount of limonene and other terpenes dominated those juices. The same relationships as in PPJ were found where terpenoids and total volatiles were depressed significantly in the serum $(36.1 \%)$ and increased significantly (108.0\%) in the pulp and cloud (Table 4). To see which volatile compounds might be partitioned, lost, or both, in juicing regimes, an evaporation procedure was used to concentrate ( $\approx 65 \%$ SSC) NFC juices from peeled fruit (PPJ, set B). The condensate (essence) was collected, and concentrates were reconstituted into $100 \%$ single-strength juice. The juice essence contained eight of the original 13 compounds with the addition of two others $(\alpha$-terpineol and decanal), likely as a result of oxidation (Table 4). The essence contained $46.3 \%$ of the total volatiles recovered in the original juice and decanal comprised $96.9 \%$ of the total essence. When the concentrate was used to reconstitute $100 \%$ single-strength juices, only four compounds remained (limonene, nonanal, $\beta$-damascenone, and valencene) at significantly reduced levels $(0.84 \%)$ of the original control, and these juices lacked most positive sensory/aroma attributes desirable in an orange juice but contained faint citrus notes (Table 5). Data indicate that a mild concentration process resulted in the loss of several key satsuma compounds and further volatile loss as juices were prepared from the reconstituted concentrates, lacking the majority of compounds associated with citrus aromas.

Serum is the clear aqueous phase [94\% in orange juice (Brat et al., 2003)] containing soluble compounds [e.g., sugars and organic acids (Scott et al., 1965)] that is a non-viscous, pale yellow liquid with little orange aroma (Baker and Bruemmer, 1969). However, several monoterpenes, terpenoids, and low MW compounds are present in the serum at severely reduced levels (Table 4), as previously reported in orange juices (Brat et al., 2003; Radford et al., 1974). The insoluble particles enhance the color, flavor, aroma, and body of the juice and are therefore highly desirable in the commercial product.

The increase in total volatiles recovered in the pulp and cloud fraction of PPJ was almost exclusively the result of limonene, $p$-cymene, $\gamma$-terpinene, $\beta$-myrcene, and valencene, which would be found in the hydrophilic pulp and cloud fraction, similar to a previous report for compounds (limonene, $p$-cymene, $\beta$-myrcene, $\alpha$-pinene, sabinene, $\alpha$-selinene, and valencene) in freshly squeezed orange juice phases (Brat et al., 2003). Several individual compounds and the total normalized volatiles in both pulp and cloud fractions (978.69 and 260.93) were significantly higher than their controls (222.42 and 51.26), respectively (Table 4). This may be the result of citrus pulp and cloud containing most of the monoterpenes (Brat et al., 2003; Radford et al., 1974) and the ability of more compounds to be driven out of the liquid phase of the pulp and cloud portion consequently adsorbed onto the SPME fibers. The water-insoluble components in orange juice have been classified as either pulp, consisting of the coarsest particles (greater than $2 \mu \mathrm{m}$ ) that tend to settle on storage, and cloud, the finer particles (less than $2 \mu \mathrm{m}$ ) (Radford et al., 1974; Rega et al., 2004). The water-insoluble pulp fraction is $4.2 \%$ in orange juice and monoterpene and sesquiterpene hydrocarbons were primarily recovered from the pulp $(74.0 \%$ and $87.2 \%$, respectively) (Brat et al., 2003). These data show the recovery for satsuma approximates previously reported values, but because samples were not centrifuged then sampled through SPME, the numerical sums reflect partitioning and equilibrium conditions of the juice and SPME phases combined.

Over $90 \%$ of the hydrocarbon (mono- and sesquiterpenes) limonene, $\beta$-pinene, and $\gamma$-terpinene were exclusively associated with pulp and cloud, and in contrast, almost all (84\% to $90 \%)$ of the esters and monoterpene alcohols were found in the serum of fresh squeezed orange juice (Brat et al., 2003). These three aforementioned terpenes constituted $79.6 \%$ and $85.3 \%$ of the pulp and cloud in two separate sets of PPJ [A and B (Table 4)]. This seems to indicate that the NFC pilot plant juices were rather stable because the partitioning between the serum vs. pulp and cloud phases changed little through short-term storage in both sets.

In preliminary runs, cheesecloth was initially used to reduce the pulp fraction in juices and to stabilize the NFC juices. Limonene dominated $(\approx 75 \%)$ these juices and filtering increased oxidation as evidenced by the appearance of decanal (Table 4). Very little volatile changes were observed in the profiles. Because settling occurred in most juices, no advantage seemed to be gained.

SubJECTIVE AND QUALITY ASSESSMENTS. WPJ had very bright orange color, excessive oil content (visual evidence), foamy surfaces, intense citrus aroma with a slightly sour and astringent aftertaste as well as marked sedimentation (Table 6). Sweetness appeared to mask their astringency, and WPJ initially scored a 3.0. The aromatic profile of WPJ was dominated by limonene (Table 3) and the associated typical attributes from peel oils (Table 5) (Choi, 2004; Elmaci and Altug, 2005). The PPJ had slightly less color (more yellow), but within grade to rank a 3.0 (Table 6). These juices had a much more balanced aromatic profile, reminiscent of freshly squeezed orange juice yet very mild (1.0). Even after peel removal, the crude PPJ still had a slight oil-like suspension on the surface after sitting at room temperature and warming. Peeled fruit delivered an acceptable but weaker flavored NFC juice compared against the WPJ. The 
Table 6. Subjective appraisals of freshly pressed satsuma juices subjected to various enzymatic treatments and storage for $7 \mathrm{~d}$ at $4{ }^{\circ} \mathrm{C}$.

\begin{tabular}{|c|c|c|c|c|c|c|c|c|c|}
\hline & \multirow[b]{2}{*}{$\begin{array}{c}\text { Whole press (A) } \\
\text { control }^{\mathrm{z}}\end{array}$} & \multicolumn{8}{|c|}{ Peeled press controls and enzyme liquefaction treatments (A) } \\
\hline Parameter & & Control & $10 \mathrm{~L}^{\mathrm{y}}$ & PTE100 & VR-C & DA6L & $\begin{array}{c}10 \mathrm{~L} \\
\text { VR-C }\end{array}$ & $\begin{array}{c}\text { PTE100 } \\
\text { VR-C }\end{array}$ & $\begin{array}{c}\text { PTE100 } \\
\text { VR-C } 10 \mathrm{~L}\end{array}$ \\
\hline \multicolumn{10}{|l|}{$\overline{\text { Day } 0}$} \\
\hline Oil surface and content & $1.0 \mathrm{~b}$ & $2.3 \mathrm{a}$ & 2.0 & 3.0 & 2.3 & 2.7 & 2.3 & 3.0 & 3.0 \\
\hline Smell/aroma & $3.0 \mathrm{a}$ & $1.0 \mathrm{~b}$ & $2.0^{*}$ & 1.0 & $3.0^{*}$ & $2.3 *$ & $3.0^{*}$ & $3.0^{*}$ & $3.0 *$ \\
\hline Sweetness & $3.0 \mathrm{a}$ & $3.0 \mathrm{a}$ & $2.0^{*}$ & 3.0 & 3.0 & 3.0 & 3.0 & 3.0 & 3.0 \\
\hline Sourness & $2.0 \mathrm{~b}$ & $3.0 \mathrm{a}$ & 2.3 & 2.7 & 3.0 & 3.0 & 3.0 & $2.0^{*}$ & 3.0 \\
\hline Sedimentation & $1.0 \mathrm{~b}$ & $3.0 \mathrm{a}$ & $2.0^{*}$ & 3.0 & 3.0 & 3.0 & 3.0 & 3.0 & 3.0 \\
\hline Separation serum, pulp, and cloud & $2.0 \mathrm{~b}$ & $3.0 \mathrm{a}$ & 3.0 & 3.0 & 3.0 & 3.0 & 3.0 & 3.0 & 3.0 \\
\hline \multicolumn{10}{|l|}{ Day 7} \\
\hline Overall color (loss orange) & $3.0 \mathrm{a}$ & $2.0 \mathrm{~b}$ & $1.0^{*}$ & $1.0^{*}$ & 2.0 & 2.0 & 2.0 & 3.0 & 2.3 \\
\hline Sourness & $3.0 \mathrm{a}$ & $2.0 \mathrm{a}$ & 2.0 & 2.0 & 1.0 & 1.0 & 2.0 & 2.0 & 1.0 \\
\hline Sedimentation & $1.0 \mathrm{a}$ & $1.0 \mathrm{a}$ & 1.0 & 1.0 & 1.0 & 1.0 & 1.0 & 1.0 & 1.0 \\
\hline Separation serum, pulp, and cloud & $2.0 \mathrm{a}$ & $1.0 \mathrm{~b}$ & 1.0 & 1.0 & 1.0 & 1.0 & 1.0 & 1.0 & 1.0 \\
\hline
\end{tabular}

${ }^{\mathrm{z}}$ Upper case letters in parentheses refer to the lot of fruit used through various analysis for data presentation.

${ }^{\mathrm{y}} 10 \mathrm{~L}=\operatorname{Rohapect}^{\circledR} 10 \mathrm{~L}(100 \mathrm{~mL} / 1000 \mathrm{~L}) ; \mathrm{VR}-\mathrm{C}=\operatorname{Rohapect}^{\circledR}$ VR-C $(30 \mathrm{~g} / 1000 \mathrm{~L}) ;$ PTE100 $=$ Rohapect ${ }^{\circledR}$ PTE100 $(7 \mathrm{~mL} / 1000 \mathrm{~L}) ; \mathrm{DA} 6 \mathrm{~L}=$ Rohapect ${ }^{\circledR}$ DA6L $(50 \mathrm{~mL} / 1000 \mathrm{~L})$. All enzymes are products of AB Enzymes (Plantation, FL).

${ }^{x}$ Whole-pressed juice (WPJ) was only compared with the $0 \mathrm{~d}$ peeled pressed juice (PPJ) $0 \mathrm{~d}$ control because initial processing methods present an unfair comparison. Means not connected by the same letter(s) are statistically different, according to a Tukey's test at $P<0.05$. Other means highlighted with an asterisk $\left(^{*}\right)$ are statistically different from PPJ control, 0 to $7 \mathrm{~d}$, per subjective observation (row), according to a Dunnett's test at $P \leq 0.05$.

pilot pasteurized satsuma juice, also used as a benchmark and to aid in training, did not have a strong sweet taste or citrus aroma (data not shown). The control satsuma juices, although pleasant, would not likely compare with what consumers associate with a regular NFC pasteurized orange juice. This is probably because essence (flavor packs) was not added back into the peeled juice products produced in the pilot plant juices we report. Nonetheless, freshly pressed, truly NFC satsuma juices produced from peeled fruit at roughly $11.0 \%$ to $11.4 \%$ SSC (Table 7 ) were very appealing and highly acceptable.

All enzyme treatments except PTE100 tended to improve the overall aroma on $0 \mathrm{~d}$, and on $7 \mathrm{~d}$, there was no effect. No enzyme treatment affected bitterness (data removed). Sedimentation and separation of insoluble vs. soluble fractions was indeed a problem in WPJ and all $7 \mathrm{~d}$-stored samples. Many commercial juices with and without pulp have significant sedimentation. Cheesecloth filtering (data not shown) and enzyme treatments did not help alleviate sedimentation. Juices that passed through the UF were distinctly weak in aromatic profiles and lacking the characteristic orange color and citrus flavor (data not shown). The UF fouled as a result of excessive pulp that effectively held back and trapped much color and soluble solids that could not pass through. From the 19 compounds surveyed, WPJ that passed through UF had $50.8 \%$ less total volatiles after $7 \mathrm{~d}$ storage (Table 4 ). The initial juices generally contained $10.5 \%$ to $11.3 \%$ SSC, which dropped to as low as $7.1 \% \mathrm{SSC}$ after UF (data not shown). The dramatic decrease in sweetness is likely why the UF juices lacked characteristic aromatic profiles, although most dominant citrus compounds were recovered (Table 4). Future direct clarification attempts with UF were therefore abandoned and focus placed on rapid enzymatic treatments.

Based on the subjective appraisals, we anticipated significant color differences between whole vs. peeled juices. However, little instrumental differences were detected on $0 \mathrm{~d}$ (Table 7). For example, peeled juices appeared lighter in color and more yellowish, but there was no clear trend in which $\mathrm{L}^{*}$ and $\mathrm{b}^{*}$ values were lower for peeled juices compared with both the whole-pressed and commercial juices (Table 7). Even calculating hue angle and total color $\left(\mathrm{C}^{*}\right)$ (data not shown) did not reveal significant color changes (Table 7). Likewise, there appeared to be few significant differences in $\mathrm{SSC}, \mathrm{pH}$, and TA between PPJ and WPJ, or enzyme treatments. Performing a standard quality marker calculation to view SSC:TA ratio did not demonstrate differences. Qualitative differences that were significantly different after $7 \mathrm{~d}$ storage were general increases for VR-C, DA6L, and combined enzyme treatments in color values, SSC, and the SSC:TA ratio (Table 7). It should be noted that SSC:TA ratio in Louisiana for marketing fresh satsuma, the "too-tart" rule, is 10:1, and it was suggested that there should also be an upper limit of 15:1 imposed later in the harvest season (a "too-sweet" rule) (Ebel et al., 2004). There is no USDA standard to our knowledge for satsuma juice, but the USDA standard ratio for orange juice SSC:TA indicates a 10:1 minimum and 20.5:1 is the maximum (USDA, 1983). All our test samples had higher ratios (greater than 23:1) than 20.5:1 from 0 through $7 \mathrm{~d}$ storage (Table 7). Ratios over 10:1 have been previously documented in satsuma (Campbell et al., 2008; Yajima et al., 1979). 
Table 7. Qualitative assessment (titratable acidity, $\mathrm{pH}$, soluble solids concentration, color, soluble solids concentration:titratable acidity ratio) of freshly pressed satsuma juices subjected to various enzymatic treatments and storage for $7 \mathrm{~d}$ at $4{ }^{\circ} \mathrm{C}$.

\begin{tabular}{|c|c|c|c|c|c|c|c|c|c|c|}
\hline \multirow[b]{2}{*}{ Parameters } & \multirow[b]{2}{*}{$\begin{array}{l}\text { Whole press } \\
\text { control }(\mathrm{A})^{\mathrm{z}}\end{array}$} & \multicolumn{8}{|c|}{ Peeled press controls and enzyme liquefaction treatments (A) } & \multirow[b]{2}{*}{$\begin{array}{c}\text { Commercial } \\
\text { pasteurized juice }^{\mathrm{x}}\end{array}$} \\
\hline & & Control & $10 \mathrm{~L}^{\mathrm{y}}$ & PTE100 & VR-C & DA6L & $\begin{array}{l}10 \mathrm{~L}+ \\
\text { VR-C }\end{array}$ & $\begin{array}{l}\text { PTE100 + } \\
\text { VR-C }\end{array}$ & $\begin{array}{c}10 \mathrm{~L}+\text { PTE100 } \\
\text { VR-C }\end{array}$ & \\
\hline \multicolumn{11}{|l|}{ Day 0} \\
\hline $\mathrm{a}^{*}$ color & $0.88 \mathrm{a}$ & $-0.02 \mathrm{~b}$ & 0.08 & 0.33 & 0.22 & 0.32 & 0.23 & 0.14 & 0.06 & $-3.49 \mathrm{c}$ \\
\hline $\mathrm{b}^{*}$ color & $15.78 \mathrm{a}$ & $11.28 \mathrm{c}$ & 12.94 & 12.17 & 13.37 & 13.36 & $13.82 *$ & 13.29 & 13.17 & $13.15 \mathrm{~b}$ \\
\hline $\operatorname{SSC}(\%)^{\mathrm{u}}$ & $11.33 \mathrm{a}$ & $11.00 \mathrm{~b}$ & 10.67 & 10.73 & 11.10 & 11.03 & 10.97 & 11.00 & 10.90 & $9.78 \mathrm{c}$ \\
\hline SSC:TA & $24.62 \mathrm{a}$ & $23.64 \mathrm{a}$ & 22.38 & 23.03 & 24.40 & 24.40 & 24.13 & 24.23 & 24.04 & $22.21 \mathrm{~b}$ \\
\hline $\mathrm{pH}$ & $3.76 \mathrm{~b}$ & $3.77 \mathrm{~b}$ & $3.70 *$ & $3.66^{*}$ & 3.79 & 3.73 & $3.83^{*}$ & $3.85^{*}$ & $3.83^{*}$ & $3.94 \mathrm{a}$ \\
\hline \multicolumn{11}{|l|}{ Day 7} \\
\hline $\mathrm{L}^{*}$ color & $34.37 \mathrm{a}$ & $27.65 \mathrm{~b}$ & 29.17 & 28.18 & 29.52 & $30.40^{*}$ & $30.92 *$ & $30.04 *$ & $30.51 *$ & \\
\hline $\mathrm{a}^{*}$ color & $-0.96 \mathrm{a}$ & $-0.52 \mathrm{~b}$ & $-0.05^{*}$ & -0.24 & $0.32 *$ & $0.14^{*}$ & $0.45^{*}$ & $0.15^{*}$ & $0.20 *$ & \\
\hline $\mathrm{pH}$ & $3.62 \mathrm{~b}$ & $3.85 \mathrm{a}$ & 3.85 & $3.66^{*}$ & 3.83 & $3.68^{*}$ & 3.87 & 3.91 & 3.78 & \\
\hline
\end{tabular}

${ }^{\mathrm{z}}$ Upper case letters in parentheses refer to the lot of fruit used through various analysis for data presentation.

${ }^{\mathrm{y}} 10 \mathrm{~L}=$ Rohapect $^{\circledR} 10 \mathrm{~L}(100 \mathrm{~mL} / 1000 \mathrm{~L}) ; \mathrm{VR}-\mathrm{C}=$ Rohapect $^{\circledR}$ VR-C $(30 \mathrm{~g} / 1000 \mathrm{~L})$; PTE100 = Rohapect ${ }^{\circledR}$ PTE100 $(7 \mathrm{~mL} / 1000 \mathrm{~L})$; DA6L $=$ Rohapect ${ }^{\circledR}$ DA6L $(50 \mathrm{~mL} / 1000 \mathrm{~L})$. All enzymes are products of AB Enzymes (Plantation, FL).

${ }^{\mathrm{x}} \mathrm{A}$ commercial-like pilot plant produced satsuma juice [labeled as: $10.09 \% \mathrm{SSC}, 0.49 \% \mathrm{TA}$ as citric acid (wt/wt) and SSC:TA ratio 20.6 ] was provided by an anonymous industrial plant in Florida.

${ }^{\text {w }} \mathrm{L}^{*}$ indicates lightness of a sample (white $=100$, black $=0$ ); $\mathrm{a}^{*}$ indicates redness when positive and greenness when negative; $\mathrm{b}^{*}$ indicates yellowness when positive and blueness when negative.

${ }^{v}$ Whole-pressed juice (WPJ) was only compared with the $\mathrm{d} 0$ peeled pressed juice (PPJ) $\mathrm{d} 0$ control because initial processing methods present an unfair comparison. Means not connected by the same letter(s) are statistically different, according to a Tukey's test at $P<0.05$. Those means highlighted with an asterisk $\left(^{*}\right)$ are statistically different from PPJ control, 0 or $7 \mathrm{~d}$, per quality parameter (row), according to a Dunnett's test at $P \leq 0.05$.

${ }^{\mathrm{u}} \mathrm{SSC}=$ percent soluble solids concentration $(\mathrm{v} / \mathrm{v})$.

${ }^{\mathrm{t}} \mathrm{TA}=$ titratable acidity expressed as percent citric acid (wt/wt).

In an HS GC/MS study to characterize aroma volatiles in juices three different satsuma mandarin cultivars, there were between 66 and 73 aroma volatiles recovered, yet only 29 constituents were common (Qiao et al., 2007). Overall, the compounds detected in the largest amount were limonene, linalool, $\gamma$-terpinene, $\beta$-myrcene, $\alpha$-pinene, and octanal (Qiao et al., 2007). In our analysis, all the aforementioned volatiles were abundant except octanal, which was not abundant, and only recovered in WPJ. Furthermore, other compounds such as $(\alpha$-pinene, $\beta$-pinene, $\alpha$-terpinene, $p$-cymene, $\alpha$-terpinolene, nonanal, 4-terpineol, decanal, and valencene) were routinely detected at appreciable levels. Several of these compounds match eight of the consensus compounds recently reported in mandarin oranges (Tietel et al., 2011), including linalool (floral, citrus), $\alpha$-terpineol (floral), 4-terpineol (woody, earthy), nonanal (piney, floral, citrusy), decanal (fatty, musty), limonene (citrus-like), $\alpha$-pinene (pine-like), and myrcene (musty, wet soil) (Table 5). Additional work would be required to pinpoint which volatiles are better indicators of positive aroma/flavor attributes in Louisiana-grown satsuma juices. Several repeated analyses would be required to positively ascribe a definitive suite of aroma important compounds to a given regional cultivar.

Alpha-terpineol and 4-terpineol were detected in the majority of PPJ reported, although they have been reported to be offflavors associated with heat treatments in mandarin juices
(Perez-Lopez et al., 2006). It is therefore plausible that lower concentrations of compounds as such are beneficial concerning aroma impact, per attributes listed in Table 5. Carvone, $(E)-$ geraniol, and $\beta$-caryophellene were not isolated in control and enzyme-treated PPJ throughout the study. Aside from an increase in valencene after enzyme treatments $(63.4 \%)$, there seemed to be no marked volatile, subjective, or quality improvements from the enzymes used in this study. Volatile compounds have been reported to reside in selected phases. For example, esters, low MW aldehydes, and alcohols are watersoluble and localized in the juice vesicles (Perez-Cacho and Rouseff, 2008a; Shaw, 1991). Juices from peeled fruit separated naturally into serum vs. pulp and cloud and recovery of low amounts of the more polar, low MW, hydrophilic compounds that should be associated with the serum were inconsistent. Juice SSC and TA (Table 7) made the juices fall into the "too-sweet" category (Ebel et al., 2004) and somewhat bland, mild citrus aromas/flavors were likely the result of the low levels of minor terpenoids, aldehyde, and alcohol "top notes." In addition, the remaining minor terpenoids, mainly associated with the pulp and cloud fraction, were possibly below their odor thresholds, especially considering the amounts of terpenes recovered from the WPJ that contained large amounts of peel oil associated terpenes compared with PPJ (Tables 3 and 4). 
Peeled fruit used to produce juices in a pilot plant, with minimal inputs, delivered an acceptable, mildly citrus-flavored, balanced acidity, sweet, NFC juice, yet a small pilot-scale peeler would be the only requisite to facilitate rapid juicing because hand-peeling would not be acceptable industrially. Although a rapid fresh NFC satsuma juice can be produced with minimal input and costs, data suggest more attention would be required to maintain the top notes and subtle volatile balance through use of industrial equipment or by adding back essence or flavor packs before bottling. Such studies, in concert with pasteurization, would help address shelf life, consumer safety, and acceptance issues.

\section{Literature Cited}

Bai, J., E.A. Baldwin, and A. Plotto. 2011. Stability of headspace volatiles in a 'Fallglo' tangerine juice matrix system at room temperature. Proc. Florida State Hort. Soc. 124:207-212.

Baker, R.A. and J.H. Bruemmer. 1969. Cloud stability in the absence of various orange juice soluble components. Proc. Florida State Hort. Soc. 82:215-220.

Baldwin, E.A., J. Bai, A. Plotto, R. Cameron, G. Luzio, J. Narciso, J. Manthey, W. Widmer, and B.L. Ford. 2012. Effect of extraction method on quality of orange juice: Hand-squeezed, commercialfresh squeezed and processed. J. Sci. Food Agr. 92:2029-2042.

Barboni, T., F. Luro, N. Chiaramonti, J.M. Desjobert, A. Muselli, and J. Costa. 2009. Volatile composition of hybrids citrus juices by headspace solid-phase micro extraction/gas chromatography/mass spectrometry. Food Chem. 116:382-390.

Bazemore, R., K. Goodner, and R.L. Rouseff. 1999. Volatiles from unpasteurized and excessively heated orange juice analyzed with solid phase microextraction and GC-olfactometry. J. Food Sci. 64:800-803.

Bazemore, R., R.L. Rouseff, and M. Naim. 2003. Linalool in orange juice: Origin and thermal stability. J. Agr. Food Chem. 51:196-199. Brat, P., B. Rega, P. Alter, M. Reynes, and J.M. Brillouet. 2003. Distribution of volatile compounds in the pulp, cloud, and serum of freshly squeezed orange juice. J. Agr. Food Chem. 51:3442-3447.

Buettner, A. and P. Schieberle. 2001. Evaluation of aroma differences between hand-squeezed juices from valencia late and navel oranges by quantitation of key odorants and flavor reconstitution experiments. J. Agr. Food Chem. 49:2387-2394.

Burdeau, C. 2005. Katrina strangles Louisiana's cherished citrus industry. 30 Sept. 2013. <http://www.enn.com/top_stories/article/16779>.

Buskey, N. 2012. Orange groves take hit from Isaac. 20 Sept. 2013. $<$ http://www.dailycomet.com/article/20120925/ARTICLES/ 120929770 ?tc $=$ ar $>$.

Campbell, B.L., R.G. Nelson, R.C. Ebel, W.A. Dozier, J.H. Campbell, and F.M. Woods. 2008. Mandarin market segments based on consumers sensory evaluations. J. Food Distrib. Res. 39:43-55.

Campbell, C. 2012. Environmental Working Group (EWG) farm subsidy database. Plaquemines Parish, Louisiana farm subsidy payments by category. 8 Sept. 2013. <http://farm.ewg.org/ regionsummary.php?fips $=22075>$.

Choi, H.S. 2004. Volatile constituents of satsuma mandarins growing in Korea. Flavour Fragrance J. 19:406-412.

Coleman, R.L. and P.E. Shaw. 1971. Analysis of valencia orange essence and aroma oils. J. Agr. Food Chem. 19:520-523.

de Araujo, E.F., L.P. de Queiroz, and M.A. Machado. 2003. What is Citrus? Taxonomic implications from a study of cp-DNA evolution in the tribe Citreae (Rutaceae subfamily Aurantioideae). Diversity Evolution 3:55-62.

Drewnowski, A. and C. Gomez-Carneros. 2000. Bitter taste, phytonutrients, and the consumer: A review. Amer. J. Clin. Nutr. 72:1424 1435.

Ebel, R.C., W.A. Dozier, B. Hockema, F.M. Woods, R. Thomas, B.S. Wilkins, M. Nesbitt, and R. McDaniel. 2004. Fruit quality of satsuma mandarin grown on the northern coast of the Gulf of Mexico. HortScience 39:979-982.

Elmaci, Y. and T. Altug. 2005. Flavor characterization of three mandarin cultivars (satsuma, bodrum, clementine) by using $\mathrm{GC} /$ MS and flavor profile analysis techniques. J. Food Qual. 28:163-170. Jia, M.Y., Q.H. Zhang, and D.B. Min. 1998. Optimization of solidphase microextraction analysis for headspace flavor compounds of orange juice. J. Agr. Food Chem. 46:2744-2747.

Jordan, M.J., K.L. Goodner, M. Castillo, and J. Laencina. 2005. Comparison of two headspace solid phase microextraction fibres for the detection of volatile chemical concentration changes due to industrial processing of orange juice. J. Sci. Food Agr. 85:1065-1071.

Jordan, M.J., K.L. Goodner, and J. Laencina. 2003. Deaeration and pasteurization effects on the orange juice aromatic fraction. LWTFood Sci. Technol. 36:391-396.

Louisiana State University AgCenter. 2012. Louisiana summaryAgricultural and natural resources; State totals. 30 Sept. 2013. $<$ http://www.lsuagcenter.com/agsummary/archive/2012/-State-Totals/ 2012StateTotals.pdf>.

Mabberley, D.J. 1997. A classification for edible Citrus (Rutaceae). Telopea (Syd.) 7:167-172.

McLafferty, F. 2000. Wiley registry of mass spectral data. 7th Ed. Wiley 7th/NIST02 software. Palisade Corp., Newfield, NY.

Miller, M.E. and J.D. Stuart. 1998. Comparison of gas-sampled and SPME-sampled static headspace for the determination of volatile flavor components. Anal. Chem. 71:23-27.

Miyazaki, T., A. Plotto, E.A. Baldwin, J.I. Reyes-De-Corcuera, and F.G. Gmitter, Jr. 2011a. Aroma characterization of tangerine hybrids by gas-chromatography-olfactometry and sensory evaluation. J. Sci. Food Agr. 92:727-735.

Miyazaki, T., A. Plotto, K. Goodner, and F. Gmitter. 2011b. Distribution of aroma volatile compounds in tangerine hybrids and proposed inheritance. J. Sci. Food Agr. 91:449-460.

Miyazawa, N., A. Fujita, and K. Kubota. 2010. Aroma character impact compounds in Kinokuni mandarin orange (Citrus kinokuni) compared with satsuma mandarin orange (Citrus unshiu). Biosci. Biotechnol. Biochem. 74:835-842.

Morris, R.A. 2010. The U.S. orange and grapefruit juice markets: History, development, growth, and change. Univ. Florida, Inst. Food Agr. Sci., Forida Coop. Ext. Serv., Gainesville, FL.

Moshonas, M.G. and P.E. Shaw. 1994. Quantitative determination of 46 volatile constituents in fresh, unpasteurized orange juices using dynamic headspace gas chromatography. J. Agr. Food Chem. 42:1525-1528.

Moshonas, M.G. and P.E. Shaw. 1997. Quantitation of volatile constituents in mandarin juices and its use for comparison with orange juices by multivariate analysis. J. Agr. Food Chem. 45:39683972 .

Nicolosi, E., Z.N. Deng, A. Gentile, S. La Malfa, G. Continella, and E. Tribulato. 2000. Citrus phylogeny and genetic origin of important species as investigated by molecular markers. Theor. Appl. Genet. 100:1155-1166.

Perez, A.G., P. Luaces, J. Oliva, J.J. Rios, and C. Sanz. 2005. Changes in vitamin $\mathrm{C}$ and flavour components of mandarin juice due to curing of fruits. Food Chem. 91:19-24.

Perez-Cacho, P.R. and R. Rouseff. 2008a. Processing and storage effects on orange juice aroma: A review. J. Agr. Food Chem. 56:9785-9796.

Perez-Cacho, P.R. and R.L. Rouseff. 2008b. Fresh squeezed orange juice odor: A review. Crit. Rev. Food Sci. Nutr. 48:681-695.

Perez-Lopez, A.J., D. Saura, J. Lorente, and A.A. Carbonell-Barrachina. 2006. Limonene, linalool, a-terpineol, and terpinen-4-ol as quality control parameters in mandarin juice processing. Eur. Food Res. Technol. 222:281-285.

Plotto, A., E. Baldwin, G. McCollum, J. Manthey, J. Narciso, and M. Irey. 2010. Effect of Liberibacter infection (huanglongbing or 'greening' disease) of citrus on orange juice flavor quality by sensory evaluation. J. Food Sci. 75:S220-S230. 
Plotto, A., C.A. Margaria, K.L. Goodner, and E.A. Baldwin. 2008. Odour and flavour thresholds for key aroma components in an orange juice matrix: Esters and miscellaneous compounds. Flavour Fragrance J. 23:398-406.

Plotto, A., C.A. Margaria, K.L. Goodner, R. Goodrich, and E.A. Baldwin. 2004. Odour and flavour thresholds for key aroma components in an orange juice matrix: Terpenes and aldehydes. Flavour Fragrance J. 19:491-498.

Qiao, Y., B.J. Xie, Y. Zhang, H.Y. Zhou, and S.Y. Pan. 2007. Study on aroma components in fruit from three different satsuma mandarin varieties. Agr. Sci. China 6:1487-1493.

Radford, T., K. Kawashima, P.K. Friedel, L.E. Pope, and M.A. Gianturco. 1974. Distribution of volatile compounds between the pulp and serum of some fruit juices. J. Agr. Food Chem. 22:1066-1070.

Rega, B., N. Fournier, and E. Guichard. 2003. Solid phase microextraction (SPME) of orange juice flavor: Odor representativeness by direct gas chromatography olfactometry (D-GC-O). J. Agr. Food Chem. 51:7092-7099.

Rega, B., N. Fournier, S. Nicklaus, and E. Guichard. 2004. Role of pulp in flavor release and sensory perception in orange juice. J. Agr. Food Chem. 52:4204-4212.

Rouseff, R.L., P.R. Perez-Cacho, and F. Jabalpurwala. 2009. Historical review of citrus flavor research during the past 100 years. J. Agr. Food Chem. 57:8115-8124.

Scott, W.C., J.T. Kew, and M.K. Veldhuis. 1965. Composition of orange juice cloud. J. Food Sci. 30:833-837.

Shaw, P.E. 1991. Fruits II, p. 305-327. In: Maarse, H. (ed.). Volatile compounds in foods and beverages. Marcel Dekker, New York, NY. Shaw, P.E. and M.G. Moshonas. 1993. Volatile components in juice from mandarin and mandarin hybrid fruit. J. Essential. Oil Res. 5:101-104. Shipp, M. 2002. Crop profile for citrus in Louisiana. 30 Sept. 2013. $<$ http://www.ipmcenters.org/cropprofiles/docs/LAcitrus.pdf $>$.

Steffen, A. and J. Pawliszyn. 1996. Analysis of flavor volatiles using headspace solid-phase microextraction. J. Agr. Food Chem. 44:2187-2193.
Swingle, W.T. and P.C. Reece. 1967. The botany of citrus and its wild relatives, p. 190-340. In: Reuther, W., H.J. Webber, and D.L. Batchelor (eds.). The citrus industry. Univ. California Press, Berkeley, CA.

Tanaka, T. 1977. Fundamental discussion of Citrus classification. Studia Citrologica 14:1-16.

Tietel, Z., A. Plotto, E. Fallik, E. Lewinsohn, and R. Porat. 2011. Taste and aroma of fresh and stored mandarins. J. Sci. Food Agr. 91:14-23.

Traub, H.P., L.W. Gaddum, A.F. Camp, and A.L. Stahl. 1932. Relation of anatomy and method of extraction to quality of satsuma orange juice. Science 76:298-299.

U.S. Department of Agriculture. 1983. U.S. Department of Agriculture. Code of Federal Regulations; 7CFR52.1557 United States standards for grades of orange juice. 10 Dec. 1982. Requirements for grades. $24 \mathrm{Feb}$. 2014. <http://www.ams.usda.gov/AMSv1.0/ getfile?dDocName=STELDEV3011864 $>$.

U.S. Food and Drug Administration. 2011. U.S. Food and Drug Administration. Code of Federal Regulations; 21CFR101.30. Food labeling. 1 Apr. 2011, 2013. Percentage juice declaration for foods purporting to be beverages that contain fruit or vegetable juice. 24 Feb. 2014. <http://www.accessdata.fda.gov/scripts/cdrh/cfdocs/ cfcfr/CFRSearch.cfm?fr $=101.30>$.

Versteeg, C., F.M. Rombouts, C.H. Spaansen, and W. Pilnik. 1980. Thermostability and orange juice cloud destabilizing properties of multiple pectinesterases from orange. J. Food Sci. 45:969971, 998.

Wilson, C.W. and P.E. Shaw. 1981. Importance of thymol, methyl Nmethylanthranilate, and monoterpene hydrocarbons to the aroma and flavor of mandarin cold-pressed oils. J. Agr. Food Chem. 29:494496.

Yajima, I., T. Yanai, M. Nakamura, H. Sakakibara, and K. Hayashi. 1979. Compositions of the volatiles of peel oil and juice from Citrus unshiu. Agr. Biol. Chem. 43:259-264.

Yang, X. and T.L. Peppard. 1994. Solid-phase microextraction for flavor analysis. J. Agr. Food Chem. 42:1925-1930. 